\title{
PROMOTING LEARNING AUTONOMY THROUGH SELF-ACCESS CENTER ACITIVITIES
}

\author{
${ }^{1}$ Isry Laila Syathroh, ${ }^{2}$ Hendra Husnussalam \\ 1islaisya@yahoo.com \\ 1,2 STKIP Siliwangi Bandung
}

\begin{abstract}
This paper attempts to shed some light on the activities and facilities in one Self-Access Center (SAC) in one university in Bandung. On the ground of this investigation, a context description of SAC in university levels is put forward followed by an overt statement of the objectives and the rationales of the study. There are three research problems being investigated: What is the typology of the SAC? What are the self-access language learning (SALL) activities and materials provided in this SAC? And how do the students perceive the self-access language learning (SALL) activities and materials? This qualitative study reveals that this SAC is categorized into supermarket typology of SAC. This is because of the SAC system offers learners the chance to look around and choose what they want to study. This system displays materials under clearly marked categories like in supermarket. This typology of SAC is suitable for all learner context (Gardner and Miller, 2008). However, this SAC still lack the materials and activities for SALL. Further development, in terms of materials and activities which can promote learning autonomy should be done. Most students $(72 \%)$ perceive positively about certain SAC facilities, such as books, resources, strong internet connection, and cozy environment of reading and writing area. However, there should be more improvement in certain SAC facilities (such as rooms for consultation with SAC tutor, TV viewing area) and certain SAC activities (such as English club and native speaker contact).
\end{abstract}

Keywords: Self-Access Center (SAC) and Self-Access Language Learning (SALL) 


\section{A. Background of The Study}

Learner autonomy has become an important issue in education since 1960. To promote autonomy, several strategies have been developed by many educational institutions. One of them is by establishing Self-Accecss Center (SAC). SAC is an educational facility which promotes the approach where students can study independently by choosing one of many different learning resources available. In other words, SAC is the place where SelfAccess Language Learning (SALL) is conducted.

The theory behind SALL is that students, especially foreign language students, learn better if they know how they learn (Klasses, 1998). Moreover, Bragarnote (2005) says that the act of learning is individual and the ideal language student is one that is responsible for his or her own learning, independence and capacity to make decisions and assume responsibilities taken.

Dickinson (1987) also states that SALL in learning a language through the use of a selfcontained learning environment which provides an independent study program with readily accessible materials, makes available a form of help. It is either through answer keys or through counseling and possibly offers the latest technology provided in the SAC.

In Indonesia, SAC is not only established in junior and senior high school levels, but also in higher educational levels. The past research was done by investigating the use of
SAC in promoting autonomy in vocational school levels (Syathroh, 2011). And this present research filled the gap by investigating the use of Self-Access Center in higher education in promoting learning autonomy to students as its customers.

Based on the background above, the writer attempts to analyze the use of Self-Access Center (SAC) in promoting learning autonomy in higher educational institution levels. Specifically, this study aims to:

1. Investigate the typology of Self-Access Center (SAC) established in one university in Bandung. In other words, this study aims at deeply taking a look at the portrait of one SAC and comparing it to the ideal pictures of SAC by the experts.

2. To observe the self-access language learning (SALL) materials provided in this SAC.

3. Investigate the students' perception on the use and facilities of SAC, whether it has optimally offered opportunities for learning and how it is valued by them.

The result of this study is expected to give contributions to three crucial aspects: theoretical, academic and practical aspects. For the theoretical aspects, the result of the study is hoped to enrich the literature and later enhance the use of Self-Access Center (SAC) which is established in many higher educational institutions in Indonesia. Academically, the result of this study is expected to provide readers (especially school managements and stakeholders) 
information about the establishment of SAC and what aspects constitute the SAC. This information will be compared to the theories that are expected may provide comprehensive portrait on the SAC which should be implemented. Therefore, practically, the portrait of SAC may become guidance for the management and stakeholders of STKIP Siliwangi about the establishment of SAC in the campus.

\section{B. LITERATURE REVIEW}

\section{Typology of Self-Access Center (SAC)}

Self-Access Center (SAC) is an educational facility which promotes the approach where students study independently choosing among different resources that are available. SAC can

also be defined as the place where SelfAccess Language Learning (SALL) is conducted. SALL is closely related to learnercentered approach, learner autonomy and self-directed learning as all focuses on students' responsibility and active participation for his or her own learning.

Self-Access is an approach to learning language, not a approach to teaching language (Gardner and Miller, 2008). It is not merely a collection of materials or a system for organizing resources. Moreover, it is an integration of a number of elements which combine to provide learning environment.

Gardner and Miller (2008) mention thirteen important elements of Self Access Center (SAC) namely: Resources (The function is to provide learning materials, authentic material, activities, technology, etc), People (The function is perform the roles as information provider, counselor, authentic language user, manager, material writer, assessor, administrator, organizer, etc.), Management (The function is to provide organization, overseeing of the system, coordination, decision-making, inter-facing with the institution, System (The function is to organize SALL facilities in a way that best support the needs of the learners), Individualization (The function is to acknowledge individual differences in learning styles, learning strategies, time and place of learning, learning level, content of learning, commitment to learning, etc.), Needs Analysis (The function is to identify learning goals and to facilitate the creation of study plan), Learner Reflection (The function is to consider language ability, progress in language learning, suitability of SALL for self, etc.), Counseling (The function is to provide advice on learning ability, advice on learning methods, negotiation of study plans), Learner Training (The function is to enhance understanding of SALL, to experience a variety of methods and to increase effectiveness in learning), Staff Training (The function is to enhance understanding of SALL and to increase effectiveness of service), Assessment (The purposes are as self-monitoring, certification and evaluation of SALL). Evaluation (The function is to decide suitability of SALL for self and to provide feedback about SALL to teachers), Material Development (The function is to 
support individualization and to improve learning opportunities).

Harmer (2007) also elaborates several characteristics of a good SAC, namely:

1. A good SAC must be good in classification system, so it will enable students to use SAC effectively.

2. A good SAC has good pathways. It means that it will guide the students to decide what and where to learn next after completing one activity.

3. A good SAC must be started with student and teacher training of using SAC. This program will help them to use the devices and facilities in SAC at the best use.

4. A good SAC must be good at its setting arrangement. The setting must help the users to learn and work in a conducive environment. That is why, as far as the researcher concerns, some SAC buildings are always incorporated with library buildings.

5. A good SAC must keep the users' interest going. It must be managed professionally by some people who concern and expert in managing it. And of course, a good SAC must be evaluated regularly to maintain and develop its quality and interest from the view its users, for example by distributing questionnaire every several month.

There are many types of Self-Access Center (SAC) system. These types are based on the various educational contexts. Gardner and Miller (2008) summarize the typology of Self-Access Center (SAC) for university contexts, which are also suitable for all learners contexts in the following table: 


\begin{tabular}{|c|c|c|c|c|}
\hline NO & $\begin{array}{c}\text { TYPOLOGY } \\
\text { OF SAC }\end{array}$ & DESCRIPTION & ADVANTAGES & $\begin{array}{c}\text { TYPES OF } \\
\text { LEARNERS }\end{array}$ \\
\hline 1 & Telephone Sales & $\begin{array}{l}\text { It has no specific location. } \\
\text { It relies on technology, } \\
\text { especially computers. } \\
\text { Learners interact with } \\
\text { their teachers by phone or } \\
\text { emails. Teachers act as } \\
\text { resources from their } \\
\text { offices answering } \\
\text { learner's questions. }\end{array}$ & $\begin{array}{l}\text { Few facilities are } \\
\text { required but contact } \\
\text { with teachers is } \\
\text { initiated by the } \\
\text { learners on a need-to- } \\
\text { know basis. }\end{array}$ & $\begin{array}{l}\text { University } \\
\text { students }\end{array}$ \\
\hline 2 & Catalogue Shop & $\begin{array}{l}\text { It runs on a menu-driven } \\
\text { system. The learners need } \\
\text { to know what they know, } \\
\text { what hey want before they } \\
\text { enter the system and need } \\
\text { to be able to use the } \\
\text { catalogue (computer or } \\
\text { manual) to search and } \\
\text { locate the materials. }\end{array}$ & $\begin{array}{l}\text { Staff control the } \\
\text { materials so the } \\
\text { security is high. It } \\
\text { requires some learner } \\
\text { training in order to use } \\
\text { the system. }\end{array}$ & $\begin{array}{l}\text { University } \\
\text { students }\end{array}$ \\
\hline 3 & $\begin{array}{ll}\text { Fast } & \text { food } \\
\text { Restaurant } & \end{array}$ & $\begin{array}{l}\text { The needs of the learners } \\
\text { are immediate. Most of the } \\
\text { learners need survival } \\
\text { language quickly. This } \\
\text { system relies on materials } \\
\text { that can be used over a } \\
\text { short period of time and } \\
\text { focus on specific skills. }\end{array}$ & $\begin{array}{l}\text { It provides a quick fix } \\
\text { for language learning } \\
\text { but it may not meet the } \\
\text { needs of every learner } \\
\text { who wants to use it. }\end{array}$ & $\begin{array}{l}\text { University } \\
\text { students }\end{array}$ \\
\hline 4 & Department Store & $\begin{array}{l}\text { The focus of this type of } \\
\text { SAC is on offering a large } \\
\text { number of boutique-like } \\
\text { centers within one large } \\
\text { SAC. This SAC caters for } \\
\text { a large number of learners } \\
\text { with differing specific } \\
\text { needs. }\end{array}$ & $\begin{array}{l}\text { Many different types } \\
\text { of learners can use the } \\
\text { sytem, but it is } \\
\text { expensive to run and } \\
\text { develop. }\end{array}$ & $\begin{array}{l}\text { University } \\
\text { students }\end{array}$ \\
\hline 5 & Technology Shop & $\begin{array}{l}\text { It relies on technology. } \\
\text { There is a large amount of } \\
\text { audio and computer } \\
\text { technology often with less } \\
\text { attention paid to } \\
\text { pedagogical input. The } \\
\text { emphasis is on motivating } \\
\text { learners into using the } \\
\text { target language with the } \\
\text { aid of technology. }\end{array}$ & $\begin{array}{l}\text { Most learners are } \\
\text { highly attracted to } \\
\text { language learning via } \\
\text { technology but it is } \\
\text { very expensive and } \\
\text { needs technical } \\
\text { assistance for } \\
\text { maintenance. }\end{array}$ & All learners \\
\hline 6 & Discount Store & $\begin{array}{l}\text { The emphasis is on } \\
\text { producing a lot of } \\
\text { materials cheaply. It can } \\
\text { be from students' } \\
\text { donation. The materials is } \\
\text { arranged under general } \\
\text { categories. }\end{array}$ & $\begin{array}{l}\text { It is cheap but the } \\
\text { pedagogical value of } \\
\text { some of the donated } \\
\text { materials may be } \\
\text { questionable. }\end{array}$ & All learners \\
\hline 8 & Supermarket & It offers learners the & It is a user-friendly & All learners \\
\hline
\end{tabular}




\begin{tabular}{|c|c|c|c|c|}
\hline NO & $\begin{array}{c}\text { TYPOLOGY } \\
\text { OF SAC }\end{array}$ & DESCRIPTION & ADVANTAGES & $\begin{array}{c}\text { TYPES OF } \\
\text { LEARNERS }\end{array}$ \\
\hline & & $\begin{array}{l}\text { opportunity to look } \\
\text { around ad choose what to } \\
\text { study. The system } \\
\text { displays materials under } \\
\text { clearly marked categories: } \\
\text { listening, reading, } \\
\text { phonology, games, etc. In } \\
\text { this way, learners can } \\
\text { independently gain access } \\
\text { to the system and easily } \\
\text { find the area they wish to } \\
\text { study. }\end{array}$ & $\begin{array}{l}\text { system. It can vary } \\
\text { from cheap to } \\
\text { expensive to establish } \\
\text { and run but this } \\
\text { system needs a lot of } \\
\text { materials to work } \\
\text { well. }\end{array}$ & \\
\hline
\end{tabular}

(Table 2.1: Typology of SAC)

\section{Self-Access Language Learning in Self- Access Center}

The SAC's primary function should be as a facility for learners to use English as they like in order to improve their language skills. Gardner and Miller (2008) describe several activities which encourage joint participation of a diverse range of learners, such as:

\section{- Workshops}

A series of short 1-2 hour workshops can be offered which should cover language skills which learners require or request. The purpose is to stimulate discussion on specific topics which learners want to know about and to guide learners in ways they can practice or develop their skills. The examples of topics are creative writing, pronunciation, speed reading, etc.

\section{- English Club}

Many institutions establish English club as a way of encouraging more natural use of the language in a non-classroom setting. This type of club could be situated in the SAC with a specific time slot each week or month. Members of the English Club may also be encouraged to volunteer to help run the SAC.

\section{- $T V$ Viewing}

Many learners who go to SAC which has TV spend some (or a lot) of their time watching TV. Their justification for this is that they want to relax and try to enjoy listening to the language. SACs should cater to this group of learners by providing comfortable chairs and a section of SAC where language learning for entertainment purposes can be enjoyed.

\section{- Native Speaker Contact}

Where learners do not have access to speakers of the target language at school, it may be possible to invite guests in to talk with the learners. These native speakers may be encouraged to wander around the SAC and to chat to learners to find out what they are doing, why they are learning the language or just chat 
socially with the learners.

\section{Some Practical Perspectives of Self-Access Center}

There are some practical items which are important in establishing a good SelfAccess Center (SAC). Gardner and Miller (2008) elaborates the items below:

\section{- Learner Profiles}

A learner profile is a collection of information relating to an individual learner (Gardner and Miller, 2008). The purpose is to provide a picture of the learner's current development and future potentials in terms which relate to self access learning. There are two major goals in creating profiles of self-access learners. The first is to establish the needs and wants of the learners. The second is to monitor the students' progress.

As a result of using profiles, students will know more about themselves and their abilities, will pursue relevant goals in their learning and will take greater responsibility for their learning. For teachers, they will have a clearer picture of their students' needs, wants and learning objectives and be better able to assist in achieving those pictures.

\section{- Materials for Self-Access Language} Learning

Gardner and Miller (2003) state that materials for Self-Access Language Learning consist of four resources, they are: published language-learning materials, authentic materials, specially produced materials and student contribution to materials.

Published language-learning materials are very useful in self-access learning, since it is a quick and easy solution to initially build up a stock of self-access materials.

Authentic materials mean any text (printed or digital) or tape which was produced for a purpose other than teaching the target language. Little at al (1989) cited in Gardner and Miller (2003) list three reasons why authentic materials make useful languagelearning materials. They feel that the authentic texts are likely to motivate learners, promote acquisition and if used in sufficient quantities, contribute to language immersion.

Specially produced materials are provided if learners' needs cannot be met with the kinds of materials available. Gardner and Miller (2003) state that specially produced materials are often enhanced by the inclusion of extracts from authentic sources (e.g. newspapers, subject specialist text books).

Student contributions to materials are intended to provide opportunities for students to become actively involved with the environment in which they are learning (Gardner and Miller, 2003). Involving learners in developing self-access materials may result in them feeling a greater 
commitment to self-access learning.

\section{- Physical Settings and Resourcing}

The physical settings, equipment and furniture used in self-access center have an important role in instilling and maintaining learners' motivation. Gardner and Miller (2003) explain that space is usually allocated by the institution. Furniture also plays an important role in creating an image for SAC. It consists of seats, desks, shelves, cupboards, filing cabinets and screens. Some technical equipment are usually used in a SAC, such as audio-recorders, computers, videotape players, laserdisc players, closed caption decoders, satellite $\mathrm{TV}$, camcorders, karaoke machine and photocopy machine.

\section{- Counseling}

A good SAC provides counselor for helping its users by doing counseling program. Choosing teachers to be SAC counselors need several considerations, such as: suitability of staff, managing timetable for counseling (by appointment or dropins), where to counsel and the purposes of having regular counseling. Gardner and Miller (2003) state the important role of a SAC counselor is to help learners find and use the materials and equipment in SAC. Reference guides are a useful tool which counselors can use to help learners. It consists of notes, descriptions and also counselors' comments of learners' development during learning in SAC.

\section{RESEARCH METHODOLOGY}

This study uses qualitative research by employing a case study design. The use of case study in research has several advantages. First, as case studies are qualitative in nature, thus they have the advantage of qualitative research which, as Johnson (1992: 76) claims, "they are primarily naturalistic, relying on the collection of naturally occurring data." In other words, the data of a case study is high in reliability for the naturalness in terms of behavior, environment and all related aspects of the events investigated. Case study is also flexible in terms of design (Yin, 1994) and in terms of the interaction of multiple factors aligned to the subject of the research (Thomas, 2003).

Two instruments of data collection (direct observation and questionnaire) were used to collect the information to answer the research questions. Based on the theory of SAC stated by Gardner and Miller (2008), specifically the researcher conducted the steps as follow: As the first step, the researcher listed some practical perspectives of the Self-Access Center stated by Gardner and Miller (2008) which were investigated, namely: the learner profiles, the materials for self-access language learning, the activities in SAC, the physical settings and resourcing, and counseling. For the second step, the researcher decided the tools of data collection, which are direct observation and questionnaire. The researcher conducted direct observation to the elements of SAC mentioned in the first step above, as well as 
distributing questionnaire to the students as its visitors. Yin (1994: 78) states that "the use of multiple source of evidence from two or more sources into a case study investigation will increase its quality substantially. Here, direct observation were conducted to see the concept of SAC, in terms of the practical ways of the implementation of the SAC. Next, a number of statements elaborated on the questionnaire were intended to gain the information about students' perspectives toward the concept of SAC in terms of enhancing them to learn English. As a result, a qualitative approach was used to interpret the finding in a descriptive way. For the last step, the researcher reported the findings in the form of a case study. Gardner and Miller (2008) say that the report finding step must be done quickly because as time passes the findings may become less relevant. According to Yin (1994:3), a descriptive case study is "allowing an investigation to retain the holistic and meaningful characteristics of real-life events." Zonabend (1992) cited in Tellis (1997) states that "case study is done by giving special attention to completeness in observation, reconstruction, and analysis of the cases under study." A case study researcher focuses on a single entity as it exists in its natural environment (Johnson, 1992). Frequently, as Thomas (2003: 33) claims, "case studies also provide the reasons why the entity acts as it does." McMillan and Schumacher (2001) also state that a descriptive research using a descriptive mode of inquiry simply describes an existing phenomenon by using numbers to characterize individuals or a group. It assesses the nature of existing conditions.

This study was conducted at Indonesia University of Education, Bandung. There are some considerations why the researchers select this institution. First, the institution is really accessible because it is near to where the researchers live. Second, the researchers are the students of postgraduate program in this institution, so it enables the researchers to reach other students who will be chosen as the participants of the study. In terms of participants, this study took 20 (twenty) SAC visitors who usually visit and study at SAC for more than twice a week. Their attendance is seen from visitor book available in SAC. So, the sampling technique for this study is random sampling.

The data taken from observation and questionnaire were analyzed differently. The data gained from direct observation were then analyzed based on the observation checklist analysis stated by Gardner and Miller (2008). Meanwhile, the students' answers gained from questionnaire were the grouped into central themes as suggested by Van Lier (1988) which are relevant to the research questions. Finally, the writer drew some conclusions in relation to the findings of this study.

\section{FINDINGS AND DISCUSSION}




\section{Finding and Discussion}

There are three research questions in this study, they are: 1) What is the typology of the Self-Access (SAC) in this university? 2) What are the self-access language learning (SALL) materials provided in this SAC? And 3) How do students perceive the use and the facilities of the SAC? To make sure that the research questions have been answered, the data gained from the instruments are elaborated and analyzed thoroughly.

The first elaboration is be related to question number 1 (What is the typology of the SelfAccess (SAC) in this university?). The SAC is classified into supermarket typology of SAC. This is due to the SAC system which offers learners the chance to look around and choose what they want to study. This is suitable with what Gardner and Miller (2008) state that supermarket typology of SAC is suitable for all learners category, either young learners, teens or adult learners. This system displays materials under clearly marked categories like in supermarket. The categories are like some language skills (reading, writing, listening and speaking) or phonology and games. In this way, learners can independently gain access to the SAC and easily find the area they wish to study. The floor plan can be seen in the appendix.

There is only one full time SAC staff who manage the SAC during the working hours (see the SAC schedule in the appendix).

The next elaboration is related to the question number 2 (What are the self-access language learning (SALL) materials provided by this SAC?). The result of the direct observation of the SALL is summarized in the following table:

\begin{tabular}{|c|c|c|c|c|}
\hline \multirow{2}{*}{ NO } & \multirow{2}{*}{$\begin{array}{c}\text { SAC } \\
\text { ELEMENTS }\end{array}$} & \multicolumn{2}{|c|}{ AVAILABILITY } & \multirow{2}{*}{ NOTE } \\
\hline & & $\mathbf{A}$ & NA & \\
\hline 1 & Learner Profiles & & $\sqrt{ }$ & $\begin{array}{l}\text { No learner profiles. Only visitor books } \\
\text { available. }\end{array}$ \\
\hline 2 & $\begin{array}{l}\text { Materials for Self- } \\
\text { Access Language } \\
\text { Learning }\end{array}$ & $\sqrt{ }$ & & $\begin{array}{l}\text { There are various kinds of published } \\
\text { language learning materials, either } \\
\text { commercially or non-commercially, such as } \\
\text { from Oxford, Cambridge, Sage, Macmillan } \\
\text { and other publishers. There are also some } \\
\text { authentic materials such as newspaper } \\
\text { (Pikiran Rakyat and The Jakarta Post). There } \\
\text { are also students' contribution to materials } \\
\text { (students created materials), like skripsi and } \\
\text { thesis. All of them are categorized into } \\
\text { research about methodology, linguistics, } \\
\text { PTA and literature. }\end{array}$ \\
\hline 3 & $\begin{array}{l}\text { Self-Access } \\
\text { Activities }\end{array}$ & & $\sqrt{ }$ & $\begin{array}{l}\text { There are only reading, writing, listening, } \\
\text { and game activities. English club, TV } \\
\text { viewing and native speaker contact are not } \\
\text { available yet. }\end{array}$ \\
\hline
\end{tabular}




\begin{tabular}{|c|c|c|c|c|}
\hline 4 & $\begin{array}{c}\text { Physical Settings } \\
\text { and Resourcing }\end{array}$ & $\sqrt{ }$ & & $\begin{array}{c}\text { Some physical settings and resourcing are } \\
\text { available, such as telephone, computers, } \\
\text { trolley, box, tape recorder, in focus, } \\
\text { photocopier, screen, audio booths, } \\
\text { catalogues, reading and writing areas. } \\
\end{array}$ \\
\hline 5 & Counseling & & $\sqrt{ }$ & $\begin{array}{c}\text { Hever, consultation room, seminar room, } \\
\text { TV viewing area are not yet available. }\end{array}$ \\
& & & $\begin{array}{c}\text { Counselor is available, however, no } \\
\text { counseling activities are available. }\end{array}$ \\
\hline
\end{tabular}

(Table 4.1.Self-Access Language Learning Materials)

And the last elaboration is related to the last

research question (How do students perceive

the use and the facilities of the SAC?).

Twenty participant students have shown

different answers to the distributed

questionnaire However, their answers can be

grouped as follow : 


\section{SALL facilities and activities in SAC}

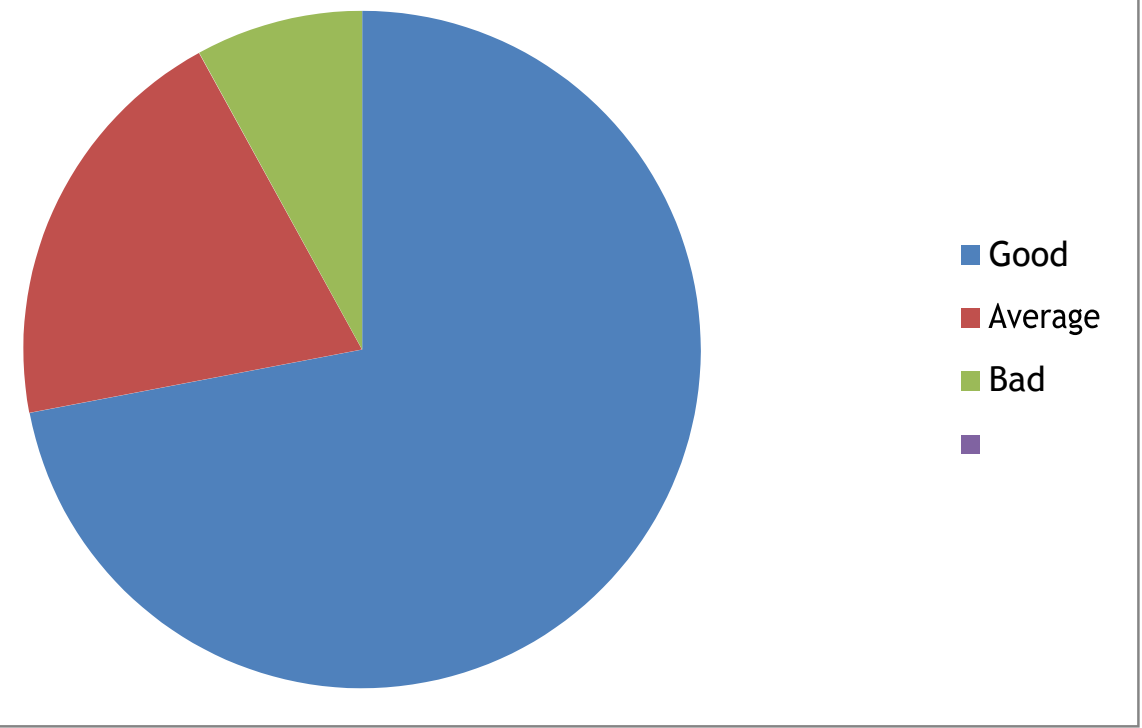

The above figure shows that $72 \%$ participants students show their positive perceptions on the SAC facilities. They said that certain facilities are good, like textbooks. The books are complete, either fiction or non-fiction, skripsi and even thesis are available in SAC. The books are very useful for independent study in SAC. Internet connection is also very strong, that is why several students always come to SAC for browsing and doing assignment. The other participant students also claim that the reading and writing area is cozy. The room is cool since the air conditioner works well, unlike in other rooms.

However, about $20 \%$ of participant students assume that the SAC materials and facilities are average, even $8 \%$ of participant students claim that the SAC materials and facilities are bad. Therefore, there should be more improvement in the facilities, since there is no rooms for consultation with SAC tutor and TV viewing area. And for the activities, some students suggest to have some activities which can enhance their language skills such as English club and native speaker contact.

\section{Conclusion}

All findings which have elaborated above lead to the conclusion that the three research questions have been answered. For the first research question about the typology if selfaccess center (SAC), it can be concluded that this SAC is categorized into supermarket typology of SAC. This is because of the SAC system offers learners the chance to look around and choose what they want to study. This system displays materials under clearly marked categories like in supermarket. This typology of SAC is suitable for all learner context (Gardner and Miller, 2008). 
self-access language learning (SALL) materials and activities are provided in this SAC, it can be concluded that this SAC still lack the materials and activities for SALL. Further development, in terms of materials and activities which can promote learning autonomy should be done.

And for the last research question about students' perception about the facilities of $\mathrm{SAC}$, it can be concluded that most of visitor $(72 \%)$ are satisfied with certain facilities, such as books, resources, strong internet connection, and cozy environment of reading and writing area. However, there should be more improvement in the facilities (such as rooms for consultation with SAC tutor, TV viewing area) and activities (English club and native speaker contact).

\section{Recommendation}

Based on the findings of this study, the writer would like to offer several recommendations related to the establishment of Self-Access Center (SAC) in STKIP Siliwangi. They are:

a. Firstly, to promote learning autonomy among students, especially dealing with students of non-regular classes, SelfAccess Center (SAC) is one of the strategies to direct the students to learn independently based on their needs and interests. This center can also be used for students to use their leisure time for something useful, like improving their language skills.

b. Last but not least, to assure the quality of Self-Access Center and its implementation, training for tutor and visitors need to be done. Tutor must be the one who is expert in his or her field, or at least has educational background related to the management of Self-Access Center. For the sake of the quality of SAC facilities, visitors must also be trained about how to use the facilities of SAC, especially when dealing with the newest technology resources.

\section{REFERENCES}

Bragarnote, M. (2005). SAC and Cooperative Learning. Linguagem \& Ensino, Vol.8, No.2, 2005 (145-169). Available at http://www.scottishcorpus.ac.uk/corpu s/search/document.php.

Desirato, O.D.B.H. and Jackson, J.H. (1976) Investigating Behavior: Principles of Psychology.

New York: Harver and Row Publisher.

Dickinson, L. (1987). Self-Instruction in Language Learning. Cambridge: Cambridge University Press.

Ding, A. (2005). Laying the Foundations for a Self-Access Center. Available at IATEFL Learner Autonomy SIG Spring 2008.

Forgus, R.H. (1966). Perception: The Basic Process in Cognitive Development. New York: McGraw Hill Book Company.

Gardner, D. and Miller, L. (2008). Establishing Self-Access: From Theory to 
Practice.

Cambridge: Cambridge University Press.

Gremmo, M. J. and Rilley, P. (1995). Autonomy, Self-Instruction and SelfAccess in Language Teaching and Learning. Available at: http://www.sisaljournal.org/archives/s $\underline{\mathrm{ep} 10}$

Harmer, J. (2007) $4^{\text {th }}$ Edition. The Practice of English Language Teaching. Cambridge, UK: Longman.

Holec, H. (1981) Autonomy and Foreign Language Learning. London: Pergamon.

Hsu, J. (2007) Intergrating a WritingAcross-Curriculum Program into a Self-Access Learning Center. Proceeding of the $24^{\text {th }}$ Conference on English Teaching and Learning. Taiwan: ERIC 496122.

Johnson, Donna M. (1992). Approaches to Research in Second Language Learning. New York: Longman.

Klassen, J. (1998). Does Self-Access Language Learning at the Tertiary Level Really Work? Asian Journal of English Language Teaching Vol.8, 1998, pp.55-80. Available at: http://www.cuhk.edu.hk/ajlt/vol8/art4

Kohayan, Aylin. (2009). The Evaluation of a Self-Access Center: A Useful Addition to Class- Based Teaching? System, Volume 37, Issue 4, December 2009, Pages 731-740. Available at www.csirus.com. Retrieved on Match 20, 2010.

Keeler, Stephen. (1982). Practising What We Preach: Teaching Teachers About SelfDirected Learning Through The Integrated Use of Self-Acces Environmentsin Teacher Training Course. System, Volume 10, Issue 3, 1982, Pages 259-268. Available at www.csirus.com.

Retrieved on Match 20, 2010.

Van Lier. 1988. In Emi Emilia's paper.

Little, D. (2000). Why Focus on Learning

Rather than Teaching. Dublin: trinity

College Press. McMillan, J. H and

Schumacher, S. (2001). Research in

Education: A Conceptual Introduction.

New York: Longman.

Morrison, Bruce. (2008). The Role of The Self-Access Center in The Tertiary Language Learning Process. System, Volume 36, Issue 2, June 2008, Pages 123-140. Available at www.csirus.com. Retrieved on March 20, 2010.

Reinders, H. (2007). Big Brother is Helping You: Supporting Self-Access Language Learning With a Student Monitoring System. System, Volume 35, Issue 1, March 2007, Pages 93- 111 Available at www.csirus.com.

Riley, P. and Gremmo, M. (1995). Autonomy, 
Self-Direction And Self Access in

Language Teaching and Learning: The

History of an Idea. System, Volume 23,

Issue 2, May 1995, Pages 151-164.

Available at www.csirus.com.

Syathroh, Isry Laila. (2011). A Case Study of Self-Access Center (SAC) in One

Vocational School in Bandung. Thesis.

Indonesia University of Education.

Tamburini, F. (1999). A Multimedia

Framework For Second Language

Teaching In Self-Access

Environments. Computers \&
Education, Volume 32, Issue 2,

February 1999, Pages 137-

149. Available at www.csirus.com.

Tellis, W. (1997) volume 3.

Introduction to Case

Study. Available at

http//www.nove.edu/sss/QR/QR3-

2/tellis1.html.

Yin, R. K. (1994) $2^{\text {nd }}$ edition. Case Study

Research Design and Methods.

Thousand Oaks, California: Sage

Publications. 